\title{
Lepidopteran Survey of Grand Teton National Park
}

\section{Authors}

K. Bagdonas, J. Carlisle, B. Davis, B. Bracewell, M. Harter, and B. Wills 


\title{
LEPIDOPTERAN SURVEY OF GRAND TETON NATIONAL PARK
}

\author{
K. Bagdonas and J. Carlisle \\ B. Davis and B. Bracewell \\ M. Harter and B. Wills \\ IBP Lab, 110 Biochemistry Building \\ University of Wyoming
}

\section{Objectives}

Beginning in 1979, a detailed survey of the macro lepidopteran fauna began in Grand Teton National Park. The three year survey, supported by UW-NPS funding, includes the following objectives:

1. Formulation of a synoptic list and voucher specimen collection of all macro lepidopteran species inhabiting Grand Teton National Park. Prior to this study, very little was known concerning the important lepidopterans or their ecology within Wyoming ecosystems and virtually nothing of scientific value had been published on the lepidopterans of the national parks in Wyoming.

2. Determination of Pleistocene "relict" or "marker" species which have survived in Grand Teton National Park. The data obtained from these "relict" species can be used in the aging and the determination of rates of species evolution within the ecosystems of the park. Related studies in Rocky Mountain National Park and elsewhere in Colorado, Wyoming and Utah (Bagdonas, 1976; Bagdonas, et al. 1977a, 1977b, 1977c, 1977d, 1978a, 1978b, 1978c, 1979a, 1979b, 1979c,1979d, 1979e, 1979f; Bagdonas, 1980a, 1980b; Bagdonas et al. 1980c, 1980d, $1980 \mathrm{e}, 1981,1982 \mathrm{a}, 1982 \mathrm{~b}, 1982 \mathrm{c}, 1982 \mathrm{~d}$, ) have indicated many lepidopteran species in the Rocky Mountains are survivors of the Pleistocene glacial and interglacial periods.

3. Determination of relative abundances, habitat preferences, seasonal flight periods, life histories, and other ecological data of Grand Teton macro lepidopterans. This data will be used toward the completion of a book for the National Park Service on the butterflies and moths of the Grand Teton National Park, and with expanded studies, also, those of Yellowstone National Park.

\section{Methods}

During the three year survey, the macro lepidopteran fauna was monitored throughout Grand Teton National Park from June through August. Aerial nets were used to collect and identify diurnal species of butterflies and moths. Nocturnal species were attracted with the aid of portable 
Bio Quip No. 2808 ultra violet lamps powered by 12 volt dry cell batteries. In addition, an electrical, mixed light trap with a 300 watt bulb, stationed at the UW-NPS Research Center, was operated as frequently as weather conditions permitted throughout the field seasons. Sugar baits were used in August of 1980 and 1981 to attract late summer species of Heterocera, many of which characteristically do not come to light.

Field photographs were taken of most recorded species. All macro lepidopteran specimens, observed and/or collected, were recorded with accompanying weather conditions and floral descriptions of the study areas. A conscious effort was made to sample all major habitat types within and around Grand Teton National Park, including the remote high altitude and talus slope areas. The majority of collected specimens have been pinned and spread. Reference collections of both diurnal and nocturnal species of macro lepidopterans within the park were formulated to increase taxonomic consistency for ourselves, regional museums, and the U.S. National Museum (Smithsonian) in Washington, D.C. In addition, unknown moth species have been turned over to specialists at the Smithsonian and the New York State Museum in Albany for classification. Micro Heterocera, although not included in this study, were also collected for specialists working in the central Rocky Mountains.

\section{Results}

The lepidopteran survey was frequently hampered by poor weather conditions during all three summers. Cold night temperatures were particularly troublesome in the collection of nocturnal moths. Nevertheless, our survey has been very productive. Table 1 shows the total number of species recorded for each family of Rhopalocera (butterflies) for 197981 , and Table 2 gives the same data for the macro Heterocera (moths) for the same time period. In the three year survey, 95 species of butterflies and shippers were recorded in 7 families, and 226 species of macro moths were likewise recorded in 17 families. The total number of 321 species in 24 families will undoubtedly be increased when experts have finished the determinations of all the unknown moths, particularly in the families Noctuidae and Geomtridae. It is our belief additional unrecorded species remain in the park. Early spring, late fall, and warm summer night collecting will surely add more macro moths to the already extensive list.

Approximately 260 of the 321 recorded lepidopterans in Grand Teton National Park are relict species with scattered colonies and disjunct populations. Their abundance within the park and surrounding areas varies from very common to extremely rare. Many of the butterflies and moths recorded represent major range extensions from more southerly isolated populations in Colorado while others are demonstrated extensions of northern boreal populations. Thus the overall lepidopteran fauna of Grand Teton National Park exhibits a unique composition of both northern and southern species. Some species within the park are actually repre- 
Table 1. The total numbers of species recorded for Rhopalocera (butterfly) families in Grand Teton National Park (1979-81).

\begin{tabular}{lc}
\hline \multicolumn{1}{c}{ Family } & No. of species \\
\hline Papilionidae & 8 \\
Pieridae & 11 \\
Lycaenidae & 28 \\
Danaidae & 1 \\
Satyridae & 8 \\
Nymphalidae & 26 \\
Hesperiidae & 13 \\
\hline Totals - 7 families & 95 species \\
\hline \multicolumn{1}{c}{ Family } & No. of species \\
\hline
\end{tabular}

Table 2. The total numbers of species recorded for macro Heterocera (moth) families in Grand Teton National Park (1979-81).

$\begin{array}{lr}\text { Sphingidae } & 10 \\ \text { Saturni idae } & 3 \\ \text { Arctiidae } & 11 \\ \text { Lithosiidae } & 1 \\ \text { Syntomidae } & 1 \\ \text { Ctenuchidae } & 1 \\ \text { Aegeriidae } & 2 \\ \text { Pericopidae } & 1 \\ \text { Agaristidae } & 2 \\ \text { Thyatiridae } & 1 \\ \text { Noctuidae } & 127 \\ \text { Notodontidae } & 8 \\ \text { Lasiocampidae } & 2 \\ \text { Liparidae } & 1 \\ \text { Platypterygidae } & 1 \\ \text { Geometridae } & 53 \\ \text { Cossidae } & 1\end{array}$

Totals -- 17 families 226 species 
sented by two different subspecies, which indicates post Pleistocene reunification of once separated populations.

\section{Conclusions}

The three year lepidopteran survey of Grand Teton National Park was completed on schedule in 1981. The study recorded 321 butterflies and macro moths in 24 families. Of these, approximately 260 or $80 \%$ represent Pleistocene "relict" species. Additional moths are expected to be added to the Heterocera list as taxonomic experts finish difficult species complexes.

\section{Literature Cited}

Bagdonas, K. 1976. The 1975 field season summary, Zone 3, Rocky Mountain Division. News of the Lepidopterists' Soc. No. 2.

Bagdonas, K., L. Draegner, I. Heller and S. Treatman. 1977a. Lepidoptera survey of Rocky Mountain National Park, 1976 annual report. Manual of Research Projects in U.S. National Parks. U.S. Dept. of the Int.

, 1977b. The 1976 field season summary, Zone 3, Rocky Mountain Division, News of the Lepidopterists' Soc. No. 2.

Bagdonas, K. and I. Heller. 1977c. High altitude relict populations of Lepidoptera in Colorado. Abstract, 153rd Ann. Meeting of the Amer. Assoc. for the Adv. of Sci., Denver, C0. February 20-25, 1977.

Bagdonas, K. 1977d. Relict moths in Colorado. Abstract, 28 th Ann. Meeting of the Int. Lepidopterists' Soc., Boulder, CO. July 21-24, 1977.

Bagdonas, K., T. Clifford, I. Heller, L. Ferrandex, L. Lee, C. Starito, R. Muzzi, L. Fillippe. 1978a. The 1977 butterfly count. Wings 11 \& 12: $6-7$.

- 1978b. Lepidopteran survey of Rocky Mountain National Park, 1977 Annual Report. Manual of Research Projects in U.S. National Parks. U.S. Dept. Int.

- 1978c. The 1977 field season summary, Zone 3, Rocky Mountain Division. News of the Lepidopterists' Soc. No. 2.

Bagdonas, K., T. Clifford, M. Harrington, S. Hill, J. Hogue, T. McGann, T. Meeks, L. Snyder, C. Sorg, C. Wilkinson, E. Williams. 1979a. The 1978 butterfly count. Wings 6(2): 5-6. 
Bagdonas, K., T. Clifford, M. Harrington, S. Hill, J. Hogue, T. McGann, T. Meeks, K. Ramsey, M. Regh, M. Schwind, L. Snyder, C. Sorg, M. Trieste, C. Wilkinson, E. Williams. 1979b. The 1978 field season summary, Zone 3, Rocky Mountain Division. News of the Lepidopterists' Soc. No. 2 .

- 1979c. Lepidoptera survey of Rocky Mountain National Park, 1978 annual report. Manual of Research Projects in U.S. National Parks. U.S. Dept. Int.

Bagdonas, K. 1979d. The butterflies and moths of Rocky Mountain National Park: a new book. Abstract, 6 th Ann. Meeting of the Int. Xerces Soc., Baltimore, MD, May 18-20, 1979.

Bagdonas, K. and M. Harrington. 1979e. Color variant adaptations, in moths in Crouse Canyon, Utah. Abstract, 30th Ann. Meeting of the Int. Lepidopterists' Soc., Fairbanks, Alaska, June 28 - July 1, 1979. News of the Lepidopterists' Soc. $5: 6$.

Bagdonas, K., T. McGann, M. Rehg, S. Blanche, A. Houston, K. Wilkinson, 1979f. Lepidopteran survey of Grand Teton National Park. U.W.-N.P. S. Research Center Third Annual Report: 7-11.

Bagdonas, K. 1980a. Important new lepidopteran records for Colorado and Wyoming. Abstract, 31 st Ann. Meeting of the Int. Lepidopterists' Soc., Gainesville, FL. June 19-21, 1980.

Bagdonas, K. 1980b. The rediscovery of Euproserpinus wiesti, a prairie sphinz moth. Abstract, 7 th Ann. Meeting of the Int. Xerces Soc., Laramie, WY. July 18-20, 1980.

Bagdonas, K., S. Blanche, J. Carlisle, T. Clifford, M. Harrington, A. Houston, T. McGann, M. Rehg, A. Tebaldi, C. Wilkinson. 1980c. 1979 butterfly count results. Supplement to Atala 7:3-6.

. 1980d. The 1979 field season summary, Zone 3, Rocky Mountain Division. News of the Lepidopterists' Soc. No. 2.

Bagdonas, K., T. McGann, M. Rehg, M. Harrington, S. Blanche. 1980e. Lepidopteran survey of Grand Teton National Park. U.W.-N.P.S. Research Center Annual Report: 17-23.

Bagdonas, K., W. Bagdonas, S. Blanche, C. Campbell, M. Crone, B. Davis, D. Geiss, M. Harrington, 1. Heller, B. Lowry, T. McGann, F. Melius, A. Overstreet, M. Rehg, R. Skinner. 1981. The 1980 field season summary, Zone 3, Rocky Mountain Division. News of the Lepidopterists' Soc. No. 2.

1982a. 1980 and 1981 butterfly count results (in press.)

Atala 9 (1\&2). 
Bagdonas, K., W. Bagdonas, S. Blanche, L. Lee, J. Carlisle, B. Davis, B. Bracewell, M. Harter, C. Tantillo, C. Farber, T. Clifford. 1982b. 1980 and 1981 butterfly count results. (In press.) Atala 9 (1\&2).

Bagdonas, K. 1982c. The butterflies and moths of Rocky Mountain National Park and surrounding areas. (In press. Rocky Mountain Nature Association).

\section{Acknowledgements}

We would again like to extend our sincere thanks to the UW-NPS Research Center staff, particularly Dr. Kenneth Diem, Director for assistance with the logistics of our project over the past three years. We also wish to thank Mr. Robert Wood of the National Park Service for his assistance with our permits. Drs. Clifford D. Ferris, of the University of Wyoming, John G. Franclement of Cornell University, Ronald W. Hodges of the Smithsonian, Tim L. McCabe of the New York State Museum, and Frederick H. Rindge of the American Museum of Natural History have all kindly helped with the classification of difficult taxonomic groups. 